\title{
The influence of Workplace Friendship for female employees' Career Success in the logistics industry
}

\author{
Jing $\mathrm{GAO}^{1, \mathrm{a}}$, Jing-Jing $\mathrm{WU}^{1, \mathrm{~b},{ }^{*}}$ \\ ${ }^{1}$ School of Management, Northwestern Polytechnical University, Xi'an, Shanxi Province, China \\ agaojnpu@nwpu.edu.cn, bxywjj2010@163.com, \\ ${ }^{*}$ Corresponding author
}

Keywords: Career Success, Workplace Friendship, Career Satisfaction, Marketability.

\begin{abstract}
An increasing number of women are pursuing self-realization in the workplace because of the opening of society. With more fierce competition and gender pressure, the female's career success will be affected by more complex factors. In this paper, we used structural equation model to test the relationship between the workplace friendship and career success by collecting data from 108 female employees in a logistics enterprise. The main findings are as follows. Workplace friendship had significant positive effects on career satisfaction, internal marketability, external marketability, which can be a basis for further research and management practice.
\end{abstract}

\section{Introduction}

With the improvement of the women's social status and ability, the focus of their lives are converting from family to career. More women want to complete the implementation of self-worth through professional development, but due to the dramatic changes of social competition and organization environment, women's career development are facing more severe challenges. Because of women's gender characteristics and limitations from general social values, which adds women more difficulties and obstacles in the pursuit of career success than men. For men and women are of different social expectations, women always confront difficulties when balancing their roles between family and work. Moreover, Women also undertake pressures caused by gender, such as discrimination, gender stereotypes [1]. Women are not afforded the same development opportunities as men are in the workplace, including training, challenging work assignments, and other forms of organizational support, in most cases women earn approximately 76 percent of their male counterparts' salaries [2]. The glass ceiling is an obstacle that keeps women from rising to top positions in organizations. These issues are gender-sensitive issues that women encounter in the pursuit of career success, which makes that when we study influencing factors on career success, we should not be simply take men and women as a same category.

Some researchers find out that women face career barriers and stressors at work that require considerable social capital to manage, it helps women to get access to inside information to leverage their social capital for career success [2].Nowadays the impact of social capital on individual career development is also growing. And compared to men, women tend to have more interpersonal demands, higher gregarious needs [3]. So from the perspective of social capital, we study the relationship between workplace friendship and career success, provide some specific suggestions for women's career development and management.

\section{Literature Review}

\section{Women's Career Success and Influencing Factors}

Career success is a positive psychological feeling or work-related achievements one has accumulated as a result of one's work experience, which includes objective career success and subjective career success. Numerous studies have found that men and women have different orientations in the treatment of career success. Men put more emphasis on achievement of the objective aspect, while women put more emphasis on subjective feelings and a good balance between work and life, moreover, women tend to be more 
concerned about relationships with other people, while men are more concerned about the chances of promotion and so on[4]. Men tend to be attributed to the success of their career path, while women regard social relationships and support as the key to their own success [5]. These phenomena indirectly indicate that the factors influencing male and female career success are not the same.

The factors influencing career success are divided into four angles. Individual perspective, including demographic variables, human capital variables, etc., organizational perspective, such as size of the organization, training and development opportunities, family perspective, emphasizing the structure of the family, etc., social perspective, putting more emphasis on the social network of employees. Compared with men, in the above four factors, family variables can well predict career success of female employees, such as delayed childbearing age, family size and a higher degree of professional success linked[6,7,8].These are associated with female characteristics. And some researchers believe that human capital and social network support are key factors in the career development of women [5].

\section{Women's Career Success and Workplace Friendship}

Although some argue that the concept of workplace friendship is vague, ambiguous, and multifaceted, there are definitional similarities among researchers. Jehn think that it involves a voluntary and amiable relationship between two employees that includes support for each other's social and emotional goals [9]. Nielsen separates it into two defining characteristics: friendship opportunity and friendship prevalence [10]. Workplace friendship is an advantage for the organization. Workplace friendships can lead to an increase in job satisfaction, job involvement, positive organizational commitment, longevity on the job, social support, communication and coordination, can enable shared values, and experiences[9,11,12,13].It can also increase institutional participation, motivate employees better serving the organizational purpose, establish supportive and innovative climates, and increase organizational productivity $[14,15,16]$.

Some researches show that women have unique relationship-oriented characters and it will be throughout their entire career development process [17]. The concept of the kaleidoscope career also illustrates that women will rely on various opportunities and constraints to evaluate their career choices in order to keep the best balance[18].Studies have shown that women's career success not only be affected by colleagues relationship,the atmosphere[19], but also be affected by the interaction among the colleagues[20]. These are showing that women's career success may be affected by workplace relationship. Among workplace relationships, friendship is unique in that it is voluntary, has a personalistic bond, and is for personal, socio-emotional benefits [21]. Because women have a higher sensitivity and feelings of workplace relationships, workplace friendship certainly has impact on women's career success.

The analysis of the social network of professional women found that women's social behavior puts more emphasis on emotional behavior, which is for the purpose of expressing emotional behavior [22]. This may be because women and men have different demands of the workplace friendship,women put more emphasis on emotional support and recognition, while men put emphasis on the recognition of status and power. If women have better relationship with superiors, they are able to receive reliable resources, information and support, and therefore, will increase the promotion chances and enhance the career satisfaction [23]. It is important for women to get support from superiors within the organization,because many important information and influence are often generated by informal, rather than formal organizational settings[24].

Thus, in this study the model depicted in the Figure 1 and the following hypotheses were proposed:

Hypothesis 1: Workplace friendships have significant effect on career satisfaction.

Hypothesis 2: Workplace friendships have significant effect on internal marketability.

Hypothesis 3: Workplace friendships have significant effect on external marketability. 


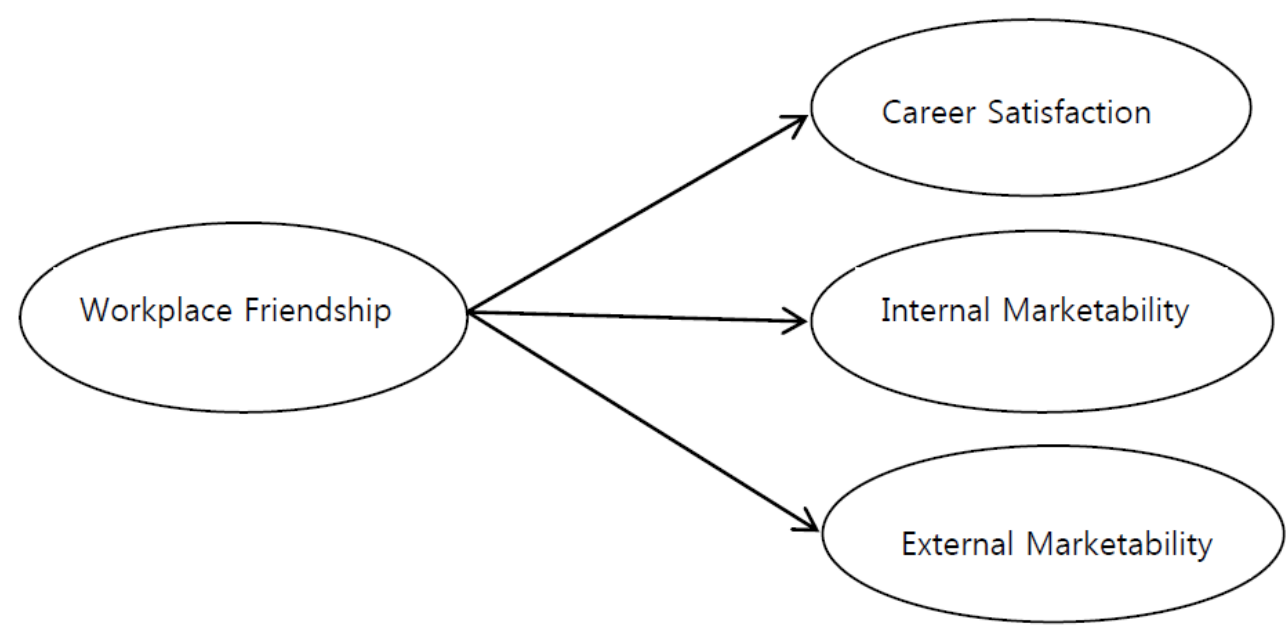

Fig. 1 The model

\section{Methodology}

\section{Sampling}

In this research,convenient sampling is used for data collection. Questionnaires were sent to 130 female employees in a logistics company in Shanghai, China. The participating employees are from managerial, technical, and finance departments. Of the 108 questionnaires that were returned, bringing the total sample to 224, with a response rate of approximately $83 \%$. Education was measured in terms of highest degree attained: 29 per cent had a high school diploma, 63 percent had a Bachelor's degree. General staffs are 76 people, accounts for $70.4 \%$, middle-level staffs are a total of 30 people, accounts for $27.8 \%$.

\section{Measures}

Career success included two parts: objective career success and subjective career success. Objective career success including internal marketability and external marketability was measured using a six items scale developed and validated by Eby[25]. The Cronbach's alpha for this scale was 0.89. Subjective career success was measured using a five items scale developed and validated by Greenhaus[26]. The Cronbach's alpha for this scale was 0.88 .

Workplace friendship was examined by the scale created from Nielsen, Jex, and Adams[27]. This scale had fourteen items, which measured workplace friendship from two perspectives, including friendship opportunity and friendship prevalence. The Cronbach's alpha for this scale was 0.90 . 5-point rating scales were used for all variables.

\section{Analysis}

We use structural equation modeling to test the relationship between workplace friendship and career success. The analyses proceeded through two stages. First, all scales were tested by confirmatory factor analysis(CFA).Next, use AMOS Software to test the hypothesizes. According to the Bollen and Long's suggestions, we choose the $\chi 2$ 、IFI、CFI、RMSEA indexes to test the scales[28].

\section{Results}

\section{Confirmatory Factor Analysis}

We used the AMOS software to test scales by confirmatory factor analysis. The results showed that the scales fit the data well. The scale of career success: $\chi 2=57.867, \mathrm{df}=41, \mathrm{p}<.01$, root mean square error of approximation $[\mathrm{RMSEA}]=.056$, incremental fit index [IFI] $=.983$, comparative fit index [CFI] $=.983$. The scale of workplace friendship: $\chi^{2}=139.617, \mathrm{df}=76, \mathrm{p}<.01$, root mean square error of approximation $[\mathrm{RMSEA}]=.088$, incremental fit index $[\mathrm{IFI}]=.919$, comparative fit index $[\mathrm{CFI}]=.918$. 


\section{Preliminary Analysis}

Table 3 reports the means, standard deviations, and correlations between the study variables. Friendship prevalence was significantly related to career satisfaction, internal marketability and external marketability. Friendship opportunity was significantly related to career satisfaction, internal marketability except external marketability.

Table 3 Means, Standard deviation and Pearson correlation Notes:*p $<.05, * * \mathrm{p}<.01, \mathrm{~N}=108$.

\begin{tabular}{|l|l|l|l|l|l|l|l|}
\hline & Means & SD & 1 & 2 & 3 & 4 & 5 \\
\hline 1 career satisfaction & 3.26 & 0.635 & 1 & & & & \\
\hline 2 internal marketability & 3.43 & 0.601 & $.420^{* *}$ & 1 & & & \\
\hline 3 external marketability & 3.35 & 0.572 & $.487^{* *}$ & $.414^{* *}$ & 1 & & \\
\hline 4 friendship prevalence & 3.23 & 0.584 & $.334^{* *}$ & $.365^{* *}$ & $.221^{*}$ & 1 & \\
\hline 5 friendship opportunity & 3.71 & 0.613 & $.247^{* *}$ & $.340^{* *}$ & .144 & $.370^{* *}$ & 1 \\
\hline
\end{tabular}

\section{Test of Hypotheses}

Figure 2 showed the results of structural equation. The results indicated support for Hypotheses 1 (b $=.44, \mathrm{p}<.01), 2(\mathrm{~b}=.46, \mathrm{p}<.01)$ and $3(\mathrm{~b}=.28, \mathrm{p}<.05)$. Workplace friendship had significant effects on women's career success: career satisfaction, internal marketability, external marketability.

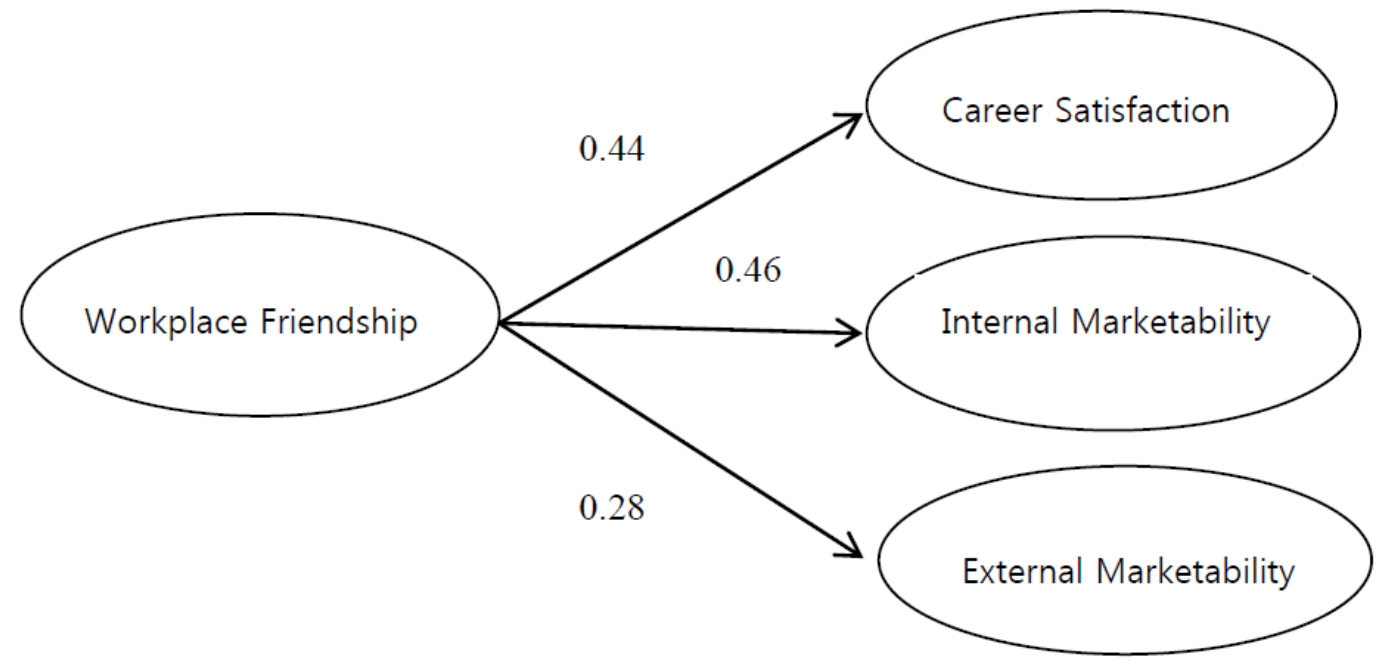

Fig. 2 Results of structural equation

\section{Discussion}

From the social capital perspective, we study the impact of workplace friendship on women's career success. Not only to refine the gender factor in career success, but also to analyze the impact factors of career success from the female's point of view, enriching the antecedents of career success, broadening the research findings of workplace friendship. The results showed that workplace friendships have main impact on career satisfaction and internal marketability. On the one hand, probably because the workplace friendship takes place in the internal organization, it has more positive impact on the outcome variable associated with the organization. On the other hand, it might because that women put more emphasis on subjective feelings and keep balance. Workplace friendship also has an impact on external marketability. The female employees who maintain good relationships with colleagues tend to have higher emotional intelligence, better interpersonal skills, which are equally important for communicating with others.

Meanwhile our findings also give some advises to management practices. Workplace friendships are beneficial to women's career success, which reminds women that they should try to establish and maintain 
such positive relationships in the workplace. Some researchers suggested that there are two main ways for professional women to maintain the network in the workplace. One is through social support, such as emotional support, job support, information support. The other one is through leisure activities and casual relationship[22].They are good for female employees to maintain good relationships in the workplace. Female employees should establish effective and active workplace relationships to promote the development of career. In this study, several limitations should be noted. The data in this study are collected from one company, so the results may have a limit in generalizability to other types of company. Second, all variables were measured at the same time point, so the results may be affected by common method variance. Future studies can not only increase the diversity of the sample sources to enhance its universality, but also take further research to the relationship between workplace friendship and career success by comparing the male and female employees.

\section{References}

[1] Liao Quanwen. On the career paths of women with university education. Southeast Academic, 1998,3 .

[2]Pamelal, Debbral. Gender and Career Success: The Facilitative Role of Political Skill. Organizational Dynamics, 2004.

[3] Sun Shijin, the social psychology ,Shanghai: Fudan University Press,2003:180 - 184.

[4]Powell, G.N. cross-currents in the river of time: conceptualising the complexities in women's careers. Journal of Management,1992.

[5] Luo Jinlian, Xiao Wei. Female career research. Foreign Economics and Management,2012.

[6]Blackburn, M. L., Bloom, D. E., Neumark, D.. Fertility timing, wages, and human capital. Journal of Population Economics, 1993,6.

[7]Budig, M. J., England, P. The wage penalty for motherhood. American Sociological Review, 2001,66(2),204- 225 .

[8]Valcour, P. M., Tolbert, P. S. Gender, family, and career in the era of boundarylessness: Determinants and effects of intra- and inter-organizational mobility. International Journal of Human Resource Management, 2003,14(5),768 - 787.

[9]Jehn KA, Shah PP. Interpersonal Relationships and Task Performance: An Examination of Mediating Processes Friendship and Acquaintance Groups. Journal of Personality and Social Psychology, 1997,72:775-790.

[10]Song SH .Workplace Friendship and Its Impact on Employees' Positive Work Attitudes. A dissertation submitted to the Graduate school - Newark Rutgers, the State University of New Jersey,2005.

[11]Sias, P. M., Heath, R. G., Perry T., Silva, D., Fix, B. Narratives of workplace friendship deterioration. Journal of Social and Personal Relationships, 2004, 21, 321-340.

[12] Snyder, M., Smith, D. Personality and friendship: The friendship worlds of self-monitoring. New York: Springer-Verlag,1986,63-80.

[13]Solano, C. H. People without friends: Loneliness and its alternatives. New York: Springer-Verlag,1986,227-246.

[14]Berman EM, West JP, Richter MN. Workplace relations: Friendship patterns and Consequence (according to managers).Public Administration Review,2000,62:217-230.

[15]Allan, G. Friendship. Boulder, CO: Westview. 1989. 
[16]Crabtree, S. Getting personal in the workplace: Are negative relationship squelching productivity in your company? .Gallup Management Journal,2004.

[17]Fletcher JK. Relational practice. Journal of Management Inquiry.1998,7(2):163-186.

[18]Mainiero LA. kaleidoscope careers :An alternate explanation for the opt out revolution. Academy of Management Executive,2005,19(1):106-123.

[19] Lu Hui, the factors influencing of women’ s career success ,Occupation temporal,2012.

[20]Monique V, Jamie J.L. Family and career path characteristics as predictors of women' s objective and subjective career success: Integrating traditional and protean career explanations. Journal of Vocational Behavior,2008.

[21]Hsiao-Yen Mao. The relationship between organizational level and workplace friendship. Human Resource Management,2006.

[22] Yang Jieyu, female occupational status attainment and reproduction in maintaining social networks, Changsha: Central South University,2004.

[23] Zhou Han, Liu Jinyan, the impact of social networks in the enterprise's senior female managers' career success. Human Resource Development of China.2012.

[24]Ragins BR, Gender gap in the executive suite: CEOs and female executives report on breaking the glass ceiling. Academy of Management Executive,1998,12(1):28-42.

[25]Eby LT, Butts M, Lockwood A. Predictors of Success in the Era of Boundaryless Careers. Journal of Organizational Behavior,2003,24:689-708.

[26]Greenhaus J.H., Parasuraman S,Wormley W.M. Effects of Race on Organizational Experiences, Job-performance Evaluations, and Career Outcomes. Academy of Management Journal,1990,33:64-86.

[27]Nielsen IK, Jex SM, Adams,G.A. Development and validation of scores on a two-dimensional workplace friendship scale. Educational and Psychological Measurement, 2000,60:628-643.

[28]Bollen K, Long JS .Testing structural equation models. Beverly Hill,CA:Sage,1993. 